\title{
Secondary School Students' Basic STEM Skill Levels according to their Self-Perceptions: A Scale Adaptation
}

\author{
Özgen Korkmaz ${ }^{1}$ \\ Amasya University, Technology Faculty, Department of Computer Engineering, Amasya, \\ Turkey ORCID: 0000-0003-4359-5692
}

\author{
Recep Çakır \\ Amasya University, Education Faculty, Department of Computer Education and Instructional \\ Technology, Amasya, Turkey ORCID: 0000-0002-2395-4769
}
Feray Uğur Erdoğmuş
Amasya University, Vocation School of Design, Department of Computer Aided Design and Animation, Amasya, Turkey ORCID: 0000-0002-9401-3405

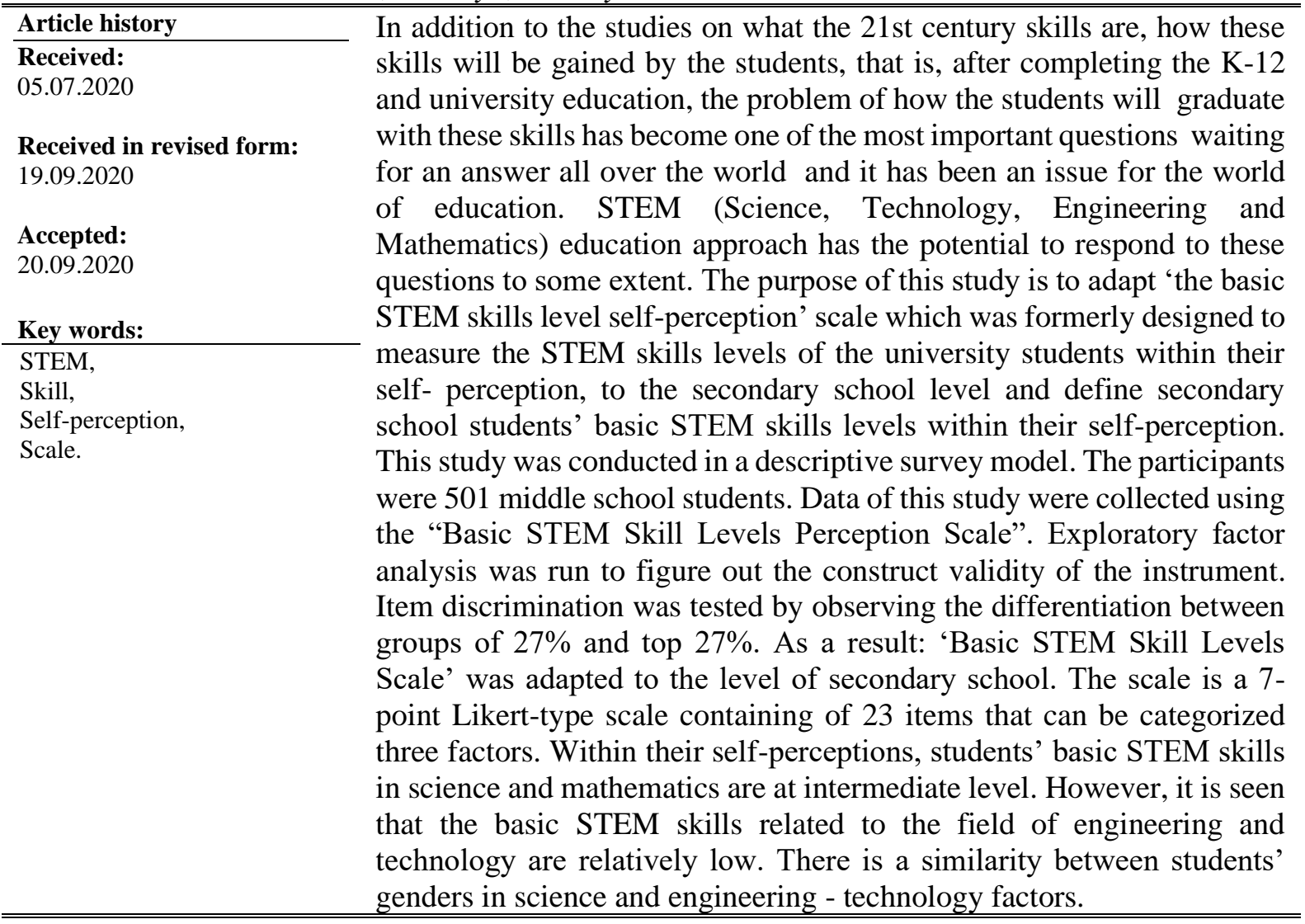

\footnotetext{
${ }^{1}$ Correspondency: ozgenkorkmaz@gmail.com
} 


\section{Introduction}

The 21st century has changed the skills that people must possess to a great extent. In fact, there is a substantial difference between the skills and abilities expected of an individual who graduated from university 50 years ago and the one who graduates from the same department today. In this context, the Partnership For 21st Century (PFC), an organization which came together with the support of the US Ministry of Education and different organizations, conducted studies on the 21 st century learning outcomes. At the end of the study, 4 basic fields were determined as the 21 st century skills and these were identified under the fields: new learning skills (innovation skills); new career skills, basic topics and 21 st century themes (besides being knowledgeable in basic science areas, global awareness; knowledge of finance, economy, business and entrepreneurship; citizenship knowledge; health information and environmental knowledge); information and technology skills (information, communication and technology literacy) (Larson \& Miller, 2011; Geisinger, 2016). On the other hand, the Organization of OECD summarized the 21st century skills under 3 main titles as knowledge (research and problem solving skills; identifying, searching, evaluating, selecting, organizing, analysing and interpreting information), communication and ethical and social impact and they called it the OECD approach (Ananiadou \& Claro, 2009).

In addition to the studies on what the 21 st century skills are, how these skills will be gained by the students, that is, after completing the K-12 and university education, the problem of how the students will graduate with these skills has become one of the most important questions awaiting for an answer all over the world and thereupon it has been an issue for the world of education. STEM (Science, Technology, Engineering and Mathematics) education approach has the potential to respond to these questions to a certain extent. The STEM concept emerged in the late 19th century and in a gradual sense it attracted more attention in the USA firstly and in Britain, Austria and many other countries (Blackley \& Howell, 2015). Taking a historical outlook on the very issue, according to Ostler (2012), STEM is not a novel concept nor a new idea. At the end of the 19th century it was used in agriculture and industry in America (White, 2014). As for STEM education approach, it was originally initiated by the National Science Foundation of America (NSF) (Sanders, 2009). The main aim of this educational initiative was to provide all students with creative problem solving and critical thinking skills that would make them more marketable in the workforce. It was thought to be an advantage for any student attending STEM education, especially at K-12 level, to choose this course. If students do not receive post-secondary education, STEM courses enable them to succeed professionally. It is thought that if the students attend a STEM-related college, then the lessons they take will be beneficial for them (Butz et al., 2004). It is witnessed that the use of STEM concepts has historically been of interest of the industrial world and has not attracted the attention of educators. However, with the help of the developing technology and especially Industry 4.0, STEM education is being used in educational environments to improve children's educational activities and prepare them for the new world emerging (White, 2014). In this sense, the main aim of STEM education is to enable integrated education of science, technology, engineering and mathematics in school. With this integrated education, it is intended to educate individuals with 21 st century skills, information literacy and adaptability to technology (Tutak, Sevil, \& Tezsezen, 2017).

Recent studies show that; countries integrate developments into their education such as industry 4.0, coding and robotics, and others to provide their students with 21 . century skills viz. creative thinking, problem solving and critical thinking skills (He \& Liang, 2019; Çakır \& Ozan, 2018; Tutak, Sevil, \& Tezsezen, 2017). It is observed that a fair number of countries have developed and implemented STEM training strategy plans. Given the importance of STEM education as 
measured research considerations, countries question the quality curriculum and the specific plans needed to develop STEM area (English, 2016). To cite an example, in the USA, the Integrated STEM Training Committee has developed recommendations for many stakeholders in STEM training (Kelley \& Knowles, 2016). Likewise, in Turkey, the Ministry of Education (MOE) published a STEM training report in 2016 and set a roadmap for the integration of the existing education STEM education approach (MOE, 2016). STEM education approach can be defined as coming up with a "common solution to a complex problem adopting an interdisciplinary approach also valid for its training rather than by independent disciplines and their fields of study and technical fields (Karataş, 2017, p.59). In other words, nowadays, students are not only intended to have basic information in STEM, but they should be able to apply knowledge from these fields in a holistic perspective to solve real life problems. In addition, students are also expected to have the 21 st century skills as mentioned above. It would be fair to state that it is not possible to provide these skills to the students with the understanding of classical education, but STEM education approach has the impending to provide these skills (Akgündüz and others, 2015).

STEM education approach mainly focuses on gaining problem-solving skills, innovativeness and designing (Hernandez et al., 2014; Yılmaz, Gülgün \& Çağlar, 2017). When analized, it is seen in the relevant literature that the STEM training has provided the students with plentiful skills. To illustrate, Y1ldırım (2016) stated in his meta-analysis study that STEM education approach positively affects students' academic achievement in the field of STEM, their problem-solving skills, creative thinking skills and attitudes and scientific skills. Furthermore, the integrated teaching of STEM areas positively affects students' learning of these subject areas (Becker \& Park, 2011). Another similar study showed that after a one-year STEM education approach in basic education, the students' knowledge of science-related knowledge and science processing skills are positively influenced (Cotabish, Dailey, Robinson \& Hughes, 2013). In his meta-analysis, Kanadl1 (2019) pinpointed that STEM education approach paves the way to the development of basic skills, to increase students' career awareness about STEM areas, to attract students' attention and to provide a fun learning environment. Another study showed that STEM-oriented technology education positively affects high school students' conceptual knowledge, advanced thinking skills and project designing activities (Fan \& Yu, 2017). In the studies investigating the effects of STEM education approach like the one handled in this manuscript, some skills are generally selected, and these skills are measured by various skill scales and achievement tests.

Despite the fact that there are studies on how STEM is implemented in education, STEM examples and the effects of STEM education approach on specific skills, there are limited studies in the literature about exactly what STEM skills are. In one of these studies, the skills needed in STEM occupational fields, which are the ultimate goal of STEM education approach, have been analysed and as a result creative/critical thinking, reading/ listening- speaking, solving complex problems, decision making, active learning, coordination, system analysis, math and science for problem solving purposes, social understanding, being instructive and using the learning strategies in appropriate places are stated to be needed for STEM professions (Jang, 2016). However, although there are ample scales in the literature to measure some of these skills separately, no scale was found to directly measure STEM skills. This study aimed to answer the need detected in this respect.

The most important thing to remember about teaching basic STEM skills to early learners is that they are perfectly adapted to learn STEM concepts, and it is not difficult to teach basic STEM skills to children (Sneideman, 2013). According to Sneideman (2013), the secret is to 
tap into their natural and innate curiosity about the living World. Furthermore, it can be said that research, problem solving and thinking skills which are assumed to be gained through STEM are indeed the basic skills that begin to be nurtured at an early age. Therefore, it can be said that it is important to acquire STEM skills at an early age. For this reason, it was thought that adapting the scale developed for university students to the level of middle school students could meet the needs in this age group. In this context, the main purpose of this research is to adapt 'the basic STEM skills level self-perception' scale which was previously designed to measure the basic STEM skills levels of the university students within their self- perception, to the secondary school level and define secondary school students' basic STEM skills levels within their self-perception. The general purpose of the study is to carry out the adaptation of the aforementioned scale. For this reason, independent variables were limited and only class level and gender variables which were thought to directly affect student development were included. The problems of the study are as below:

1) Is the Basic STEM Skill Levels Scale a valid and reliable scale that can be used at the secondary school level?

2) How are the students' perceptions of basic STEM skill levels within their selfperceptions?

3) Are their perceptions of basic STEM skill levels differentiated by gender?

4) Are the perceptions of basic STEM skill levels differentiated according to classes?

\section{Method}

\section{Research Design}

In addition to being a scale study, this study was conducted in a descriptive survey model. Thence, students' perceptions about basic STEM skill levels were attempted to be determined.

\section{Participants}

The accessible universe consists of secondary school students studying in Amasya city Centre. The participants of this study were selected by using Convenience sampling method from non-probable sampling types. In this context, the participants consist of a total of 501 students studying in different secondary schools in Amasya city Centre. The distribution of students is summarized in Table 1.

Table 1. Distribution of the study group

\begin{tabular}{lllll}
\hline & & Female & Male & Total \\
\hline Grade & 5,00 & 11 & 12 & 23 \\
& 6,00 & 37 & 29 & 66 \\
& 7,00 & 126 & 126 & 252 \\
& 8,00 & 71 & 89 & 160 \\
Total & 245 & 256 & 501 \\
\hline
\end{tabular}

\section{Instrument}

Data of this study were collected using the "Basic STEM Skill Levels Perception Scale" which was improved by Korkmaz, Çakır and Uğur Erdoğmuş (2020). A pilot study was conducted with 723 students at the Education Faculty and Technology at Amasya University for the original scale. In this study, whether the scale was valid and reliable at secondary school level was examined. The original 7-point Likert type scale consists of 43 items and three factors. 
Factors, item numbers and internal consistency coefficients included in the instrument are given in Table2.

Table 2. Internal consistency coefficients and item numbers

\begin{tabular}{lll}
\hline Factors & Item Count & Cronbach's Alpha \\
\hline Science & 20 & .950 \\
Engineering and Technology & 15 & .940 \\
Mathematic & 8 & .848 \\
Total & 43 & .969 \\
\hline
\end{tabular}

\section{Scale Adaptation Process}

It was stated that, whilst the item pool of the original scale was being created, articles capable of answering the following questions outnumbered the others (Korkmaz and others, 2020): What skills are intended to be improved with STEM education approach? How does a student with STEM skills behave? What makes us think that a student has STEM skills? What are the learning outcomes aimed at the end of the STEM process? What is the evidence that students have STEM skills? In addition, it was also stated that the learning outcomes at different class levels in the rubrics and curriculums presented on the Stanford NGSS Assessment Project (SNAP, 2018) and Next Generation Science Standards' (NGSS, 2018) web page were converted to the area independently and added to the pool of items. However, in the original scale, all the achievements in this rubric and curriculum from secondary school to university level were included in the article pool, in the adaptation process for secondary school level, 15 items which were added in line with the achievements at high school and university level were removed and in the original scale only the items of primary and secondary level were used. The language characteristics of the remaining items were examined, and corrections were made with the concern that some items could not be understood by middle school students. Two secondary school students from each class level were asked to read the final draft scale and they were asked to explain what they understood. At the end of this process, three items that students had difficulty in understanding were re-expressed. After this process, the draft scale form consisting of 28 items was examined by a science education, two educational technology and a measurement and evaluation specialist and the draft form was finalized. After the draft scale form was created this way, the scale was applied to 501 students to assess its factor, reliability and the reliability of the scale scores. Based on the data obtained from the implementation, the factor structures for this form of the scale were examined. After the draft scale, the data obtained were uploaded to SPSS to perform the validity and reliability analyses of the instrument. The validity of the original factor structure at the secondary school level was examined with exploratory factor analysis and it turned out to be suitable. Internal consistency analysis (Cronbach's alpha) was run on the data to calculate the scale reliability.

\section{Data Analysis}

Firstly, KMO and Bartlett test analysis were run to identify the need for factor analysis. Based on the values, exploratory factor analysis (EFA) was run; the factorization of the scale was set by the principal component analysis; factor loads were also investigated using Varimax vertical rotation technique. As a result, the item discriminant powers of the items were tested by the independent sample $t$ test. The Pearson's correlation test was run for item-total correlations. Item discrimination was tested by observing the differentiation between groups of $27 \%$ and top $27 \%$. In order to assess the reliability of the instrument, internal consistency coefficients and stability tests were run. Cronbach alpha coefficient was used to assess the internal consistency. Test-retest technique was used to determine the stability level. Mean, 
standard deviation, minimum, maximum values, independent sample t test and ANOVA analyses were performed to determine the self-perception of the STEM skill level of the students. $\mathrm{P}<0.05$ significance level was found to be sufficient in the difference analysis.

\section{Result}

\section{Validity}

The main construct validity, item-total correlations and discriminant levels were calculated within the framework of the validity analysis of the Basic STEM Skill Levels Selfperception Scale and the results are presented following section.

\section{Construct validity}

Kaiser-Meyer-Oklin (KMO) and Bartlett tests were used to determine whether factor analysis could be performed on collected data and it was tested whether EFA would be performed on collected data (Tatlidil, 2002). Results showed that KMO $=0.971$; the value of Bartlett test $\chi^{2}=9463.7 ; \mathrm{df}=703(\mathrm{p}=0.000)$. In this context, it can be said that the data set is perfectly suitable for factor analysis (Field, 2000; Russell, 2002). However, since the factor loads of the three items in the draft form were found to be below 0.40 , these items were excluded. It is seen that in the remaining items, the loads of the factor are between 0.438 and 0.638. According to this, all the remaining items can be said to be extremely good. In this context, EFA's were run on the data; the factorization was defined by the principal component analysis; factor loads were also investigated by using technique of the Varimax vertical rotation. Factor analysis was referred to with a view to finding out whether the substances in the instrument are divided into fewer factors (Balc1, 2009; Carmines, 1982). In this context, it is necessary to discard the substances which have a factor load of less than 0.40 and have a difference of at least 0.100 between the 2 factors. For this reason, two items which were determined to be distributed to more than one factor were excluded from the scale. When the natural factor distributions of the substances were calculated according to the factor loads obtained in the first analyses, it was determined that there were three factors with self-value above 1. Considering that the original scale consists of three factors, this structure was preserved. So as to be able to determine how the five items removed from the scale affected the content validity, the 23 items obtained were presented to the expert opinion again and EFA was run on the remaining on the basis of the opinions that the content validity was not spoiled.

In its last form, the KMO value of the 23 -item was 0.960 ; values of Bartlett test were $\chi^{2}=$ 5100.5; df $=253 ; \mathrm{p}<0.001$. The main criterion for evaluating EFA results is factor loadings (Balc1, 2009; Eroğlu, 2008; Gorsuch, 1983). Since factor loadings are high, the item can be included in the factor (Büyüköztürk, 2002). The factor loads of the lasting 23 items were between 0.412 and 0.638 . On the other hand, these were observed to be between 0.514 and 0.705 after the technique of varimax rotation. The explanation of at least $40 \%$ of the general variance in the literature is considered sufficient in terms of behavioral sciences (Eroğlu, 2008; Kline, 1994; Scherer et al., 1988). It was defined that the items in the instrument explained $52.23 \%$ of the total. The contents were concluded that they were collected under the themes of Science, Mathematics and Engineering and Technology as explained in the original and the factor structure in the original scale was preserved. As a result of these procedures, the data on the remaining 23 items according to the factors, the eigenvalues and the variance of the factors are as following in Table3. 
Table 3. Factor Analysis Results

\begin{tabular}{|c|c|c|c|c|c|c|}
\hline & I. No & Items & $\begin{array}{l}\text { Factor } \\
\text { loads }\end{array}$ & F1 & $\mathbf{F 2}$ & $\mathbf{F 3}$ \\
\hline \multirow{11}{*}{ 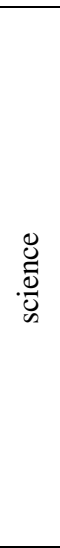 } & 2 & I can design something based on the information I gather. & 0.545 & 0.692 & & \\
\hline & 11 & $\begin{array}{l}\text { I can design a simple problem given material, time and cost } \\
\text { constraints and success criteria. }\end{array}$ & 0.543 & 0.670 & & \\
\hline & 12 & $\begin{array}{l}\text { I can show the evidence I collect for solution of a problem in the } \\
\text { form of graphic or table. }\end{array}$ & 0.541 & 0.656 & & \\
\hline & 13 & I can create different solutions to a problem. & 0.519 & 0.626 & & \\
\hline & 5 & I can analyse a problem to its smallest components. & 0.484 & 0.618 & & \\
\hline & 15 & About any problem, I can design something to solve the problem. & 0.507 & 0.606 & & \\
\hline & 14 & I can consider all the details in order to understand a topic. & 0.506 & 0.586 & & \\
\hline & 19 & I can gather scientific evidence to solve the problem. & 0.517 & 0.582 & & \\
\hline & 4 & I can make estimates by making measurements related to a case. & 0.471 & 0.566 & & \\
\hline & 10 & I can collect information to make a design. & 0.527 & 0.559 & & \\
\hline & 20 & $\begin{array}{l}\text { I can take into account even the smallest details when developing } \\
\text { a model. }\end{array}$ & 0.484 & 0.555 & & \\
\hline \multirow{6}{*}{ 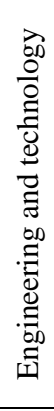 } & 30 & I can suggest a mathematical model to solve a problem. & 0.632 & & 0.712 & \\
\hline & 25 & $\begin{array}{l}\text { I can apply scientific principles to build a device to solve a } \\
\text { problem. }\end{array}$ & 0.638 & & 0.672 & \\
\hline & 28 & $\begin{array}{l}\text { I can apply scientific principles to design a device to solve a } \\
\text { problem. }\end{array}$ & 0.412 & & 0.631 & \\
\hline & 29 & $\begin{array}{l}\text { I can test a model by setting up an experimental setup in the } \\
\text { laboratory. }\end{array}$ & 0.475 & & 0.610 & \\
\hline & 32 & $\begin{array}{l}\text { I can use the properties of integers to equalize both sides of an } \\
\text { equation }\end{array}$ & 0.523 & & 0.562 & \\
\hline & 27 & $\begin{array}{l}\text { In order to understand a topic, I can collect information related } \\
\text { to each other in a model. }\end{array}$ & 0.523 & & 0.514 & \\
\hline \multirow{8}{*}{ 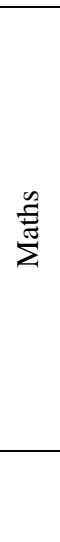 } & 38 & $\begin{array}{l}\text { I can work with other friends in a research project designed to } \\
\text { solve a problem. }\end{array}$ & 0.533 & & & 0.705 \\
\hline & 37 & $\begin{array}{l}\text { I use proportioning and reasoning to solve the problems I } \\
\text { encounter in everyday life. }\end{array}$ & 0.558 & & & 0.614 \\
\hline & 6 & $\begin{array}{l}\text { With all the evidence in hand, I can put forward claims on a } \\
\text { subject. }\end{array}$ & 0.530 & & & 0.571 \\
\hline & 34 & $\begin{array}{l}\text { I am aware that positive and negative numbers can indicate a } \\
\text { direction. (for example, }-3 \text { degrees below zero, above }+4 \\
\text { degrees) }\end{array}$ & 0.438 & & & 0.567 \\
\hline & 35 & I use proportioning and reasoning to solve math problems. & 0.547 & & & 0.535 \\
\hline & 36 & $\begin{array}{l}\text { I can use mathematical expressions to explain a simple model } \\
\text { about scientific fields. }\end{array}$ & 0.559 & & & 0.452 \\
\hline & & Eigenvalues & & 5.22 & 3.758 & 3.05 \\
\hline & & Explained Variance & & 22.67 & 16.30 & 13.2 \\
\hline
\end{tabular}

As shown in Table3, the factor contains 11 items and the factor loadings vary between 0.555 and 0.692. The eigenvalue of this factor in the overall scale is 5.22; the amount it contributes to the variance is $22.67 \%$. The Engineering and Technology factor includes 6 items. Item factor loads are between 0.514 and 0.712 The eigenvalue is 3.758 and its contribution to the variance is $16.30 \%$. The math factor includes 6 items. The factor loadings of the items are between 0.452 and 0.705 . The eigenvalue of the factor in the overall scale is 3.05; its contribution to the general variance is 13.2. The factors were mostly consistent with the original scale, but the two items were observed to shift under different factors. On the original scale while the item 'I can use the properties of integers to equalize both sides of an equation" is gathered under the Math factor, it is seen that on the adapted scale that this item is gathered under the Engineering and Technology factor. Along with that, although the item "With all the evidence in hand, I can put forward claims on a subject" is gathered under the Science factor on the original scale, it is gathered under the Math factor on the adapted scale. 


\section{Item Factor Total Correlations}

The correlation between the points gained from each item and the points acquired from the factors were calculated and the serviceability level of each item to the objective was run according to the method of the item total correlation.

Table 4. Item - Factor Total Correlations

\begin{tabular}{|c|c|c|c|c|c|}
\hline \multicolumn{2}{|c|}{$\begin{array}{c}\text { F1 } \\
\text { Science }\end{array}$} & \multicolumn{2}{|c|}{$\begin{array}{c}\text { F2 } \\
\text { Engineering and Technology }\end{array}$} & \multirow{2}{*}{\multicolumn{2}{|c|}{$\begin{array}{c}\text { F3 } \\
\text { Mathematic } \\
\mathrm{r} \\
\end{array}$}} \\
\hline I & $\mathrm{r}$ & I & $\mathrm{r}$ & & \\
\hline 2 & $0.699 * *$ & 30 & $0.756^{* *}$ & 38 & $0.632 * *$ \\
\hline 11 & $0.712 * *$ & 25 & $0.759 * *$ & 37 & $0.735 * *$ \\
\hline 12 & $0.730 * *$ & 28 & $0.722 * * *$ & 6 & $0.701 * *$ \\
\hline 13 & $0.724 * *$ & 29 & $0.692 * *$ & 34 & $0.689 * *$ \\
\hline 5 & $0.690 * *$ & 32 & $0.681 * *$ & 35 & $0.747 * *$ \\
\hline 15 & $0.707 * *$ & 27 & $0.714 * *$ & 36 & $0.741 * *$ \\
\hline 14 & $0.718 * *$ & & & & \\
\hline 19 & $0.730 * *$ & & & & \\
\hline 4 & $0.694 * *$ & & & & \\
\hline 10 & $0.651 * *$ & & & & \\
\hline 20 & $0.706^{* *}$ & & $\mathrm{~N}=501 ; * *$ & & \\
\hline
\end{tabular}

In the Table 4 , the correlation coefficients range from 0.651 to 0.730 for the first factor; for the second, 0.681 to 0.759 ; for the third 0.632 and 0.747 . Each item is significantly and positively associated with the total factor $(\mathrm{p}<0.000)$. Accordingly, it can be said that each item attends to the objective of the factor.

\section{Item discrimination}

The item discrimination was tested. Firstly, raw points gained from the scale were listed from high to low and then forming the lower $27 \%$ and upper $27 \%$ groups, groups of 135 people were defined. Independent sample t-test scores were tested over the total scores. Table 5 presents the findings about the $t$ scores and significance levels of discrimination.

Table 5. Item discriminatory powers

\begin{tabular}{|c|c|c|c|c|c|}
\hline \multicolumn{2}{|c|}{$\begin{array}{c}\text { F1 } \\
\text { Science }\end{array}$} & \multicolumn{2}{|c|}{$\begin{array}{c}\text { F2 } \\
\text { Engineering and Technology }\end{array}$} & \multirow{2}{*}{\multicolumn{2}{|c|}{$\begin{array}{c}\mathbf{F 3} \\
\text { Mathematic } \\
\mathrm{t}\end{array}$}} \\
\hline I & $\mathrm{t}$ & I & $\mathrm{t}$ & & \\
\hline 2 & $16.372 *$ & 30 & $19.155^{*}$ & 38 & $11.036^{*}$ \\
\hline 11 & $18.807 *$ & 25 & $20.525^{*}$ & 37 & $16.466^{*}$ \\
\hline 12 & $19.099 *$ & 28 & $19.472 *$ & 6 & $15.366^{*}$ \\
\hline 13 & $18.951 *$ & 29 & $14.468^{*}$ & 34 & $13.123 *$ \\
\hline 5 & $17.913 *$ & 32 & $22.753^{*}$ & 35 & $16.876^{*}$ \\
\hline 15 & $16.091 *$ & 27 & $20.238^{*}$ & 36 & $18.066^{*}$ \\
\hline 14 & $17.943 *$ & & & F1 & $37.953 *$ \\
\hline 19 & $19.520 *$ & & & F2 & $31.593 *$ \\
\hline 4 & $17.120 *$ & & & F3 & $26.332 *$ \\
\hline 10 & $13.593 *$ & & & FT & $44.798 *$ \\
\hline 20 & $21.272 *$ & & & \multicolumn{2}{|c|}{ *df: $268 ; p<, 001$} \\
\hline
\end{tabular}

It is displayed in Table 5 that the independent sample $t$ test values for 23 items, factors and points in the scale ranged from 13.123 to 22.753 . The overall value of the scale was determined as 44.798. The $t$ values for the factor scores ranged from 26.332 to 37.953 . The level of each difference was significant $(\mathrm{p}<0.001)$. It can be expressed that the general and items have a high discrimination. 


\section{Findings Related to the Reliability}

\section{Internal Consistency Level}

Reliability of the scale and the factors was tested by analyzing of the Cronbach's Alpha. The values reliability for each factor and the overall are given in Table 6;

Table 6. Reliability Level of the Scale

\begin{tabular}{lll}
\hline Factors & Item Count. & Cronbach's Alpha \\
\hline Science & 11 & 0.899 \\
Engineering and Technology & 6 & 0.858 \\
Mathematics & 6 & 0.800 \\
Total & 23 & 0.940 \\
\hline
\end{tabular}

As shown in Table 6; the reliability coefficient was calculated as 0.940 . Scores of the Cronbach's Alpha for the factors ranged between 0.800 and 0.899 ., both the factor and the scale can make consistent measurements.

\section{Consistency Level}

The consistency level was determined by the test-retest technique. The 23 -item was tested with the 32 students again after four weeks. The ability of both the scale and the items on it to make consistent was run and the results are given in Table 7.

Table 7. Consistency level of the scale

\begin{tabular}{|c|c|c|c|c|c|}
\hline \multicolumn{2}{|c|}{$\begin{array}{c}\text { F1 } \\
\text { Science }\end{array}$} & \multicolumn{2}{|c|}{$\begin{array}{c}\text { F2 } \\
\text { Engineering and Technology }\end{array}$} & \multirow{2}{*}{\multicolumn{2}{|c|}{$\begin{array}{c}\text { F3 } \\
\text { Mathematic } \\
\text { I }\end{array}$}} \\
\hline I & $\mathrm{r}$ & I & I & & \\
\hline 2 & $0.328 * *$ & 30 & $0.501 * *$ & 38 & $0.409 * *$ \\
\hline 11 & $0.421^{* *}$ & 25 & $0.375^{* *}$ & 37 & $0.365^{* *}$ \\
\hline 12 & $0.386^{* *}$ & 28 & $0.394 * * *$ & 6 & $0.475^{* *}$ \\
\hline 13 & $0.424^{* *}$ & 29 & $0.692 * *$ & 34 & $0.463^{* *}$ \\
\hline 5 & $0.501^{* *}$ & 32 & $0.403 * *$ & 35 & $0.509 * *$ \\
\hline 15 & $0.391^{* *}$ & 27 & $0.417 * *$ & 36 & $0.512 * *$ \\
\hline 14 & $0.417 * *$ & & & & \\
\hline 19 & $0.524 * *$ & & & & \\
\hline 4 & $0.482 * *$ & & & & \\
\hline 10 & $0.416^{* *}$ & & & & \\
\hline 20 & $0.492^{* *}$ & & $\mathrm{~N}=501 ; *$ & & \\
\hline
\end{tabular}

The correlation coefficients of each item in Table 7 were found to be between 0.365 and 0.524 , and each relationship was positively significant. It is clearly seen that the scale can make stable measurements.

\section{Findings related to secondary school students' STEM skills}

Table 8 summarizes basic STEM skill levels of the students

Table 8. Students’ Basic STEM Skill Levels

\begin{tabular}{lccccc}
\hline Factors & N & $\overline{\mathbf{X}}$ & Sd & Min & Max \\
\hline Science & & & & & \\
Engineering and Technology & 501 & 52,59 & 15,61 & 8 & 77 \\
Mathematic & & 26,11 & 9,606 & 1 & 42 \\
\hline
\end{tabular}

As can be seen in Table 8, the basic skill scores of the students in the field of science vary 
between 8-77 and the average is $(\overline{\mathbf{X}})=52.59$. Students got a minimum of 8 and a maximum of 77 from this factor. According to this, it is possible to say that the students' STEM basic skills related to the science field are at an intermediate level. The basic skill scores of the students in the field of Engineering and Technology vary between $1-42$ and the average is $(\overline{\mathbf{X}})=26.11$. Students could get a minimum of 1 and a maximum of 42 from this factor. Accordingly, it can be articulated that the students have little lower STEM basic skills in the field of Engineering and Technology. The basic skill scores of the students in the field of Mathematics vary between $1-42$ and the average is $(\overline{\mathbf{X}})=30.01$. Students could get a minimum of 1 and a maximum of 42 from this factor. Accordingly, it can be said that the students' basic STEM skills related to mathematics are at intermediate level. Table 9 summarizes the findings of students' basic STEM skill levels by gender.

Table 9. The effect of gender on the STEM skills of students

\begin{tabular}{lllccccc}
\hline Factors & & $\mathbf{N}$ & $\overline{\mathbf{X}}$ & $\mathbf{s d}$ & $\mathbf{t}$ & $\mathbf{d f}$ & $\mathbf{p}$ \\
\hline \multirow{2}{*}{ Science } & Female & 245 & 52,67 & 16,51 & \multirow{2}{*}{0.113} & & 0.910 \\
\multirow{2}{*}{ Engineering and Technology } & Male & 256 & 52,52 & 14,73 & & & \\
\multirow{2}{*}{ Mathematic } & Female & 245 & 25,95 & 10,28 & -0.362 & 499 & 0.718 \\
& Male & 256 & 26,26 & 8,92 & & & 0.025 \\
\hline
\end{tabular}

Although there is no significant difference between students' Science $(\mathrm{t}(2-499)=0.113 ; \mathrm{p}>0.05)$ and Engineering-Technology $(\mathrm{t}(2-499)=0.362 ; \mathrm{p}>0.05)$ factors related to their gender, there is a significant difference in terms of Maths factor $(\mathrm{t}(2-499)=2.248 ; \mathrm{p}<0.05)$. When the averages are examined, it is seen that differentiation is in favor of female students. Accordingly, it can be accentutaed that when it comes to their gender, secondary school students are similar in terms of Science, Engineering- Technology yet it is also observed that female students have significantly higher skill levels at basic Maths compared to the male ones. Table 10 summarizes the findings of the basic STEM skill levels of the students according to their learning level.

Table 10. Basic STEM Skill Levels of Students by Grade

\begin{tabular}{|c|c|c|c|c|c|c|c|}
\hline \multirow[t]{2}{*}{ Grade level } & \multirow[t]{2}{*}{$\mathbf{N}$} & \multicolumn{2}{|c|}{ Science } & \multicolumn{2}{|c|}{$\begin{array}{l}\text { Engineering and } \\
\text { Technology }\end{array}$} & \multicolumn{2}{|c|}{ Mathematic } \\
\hline & & $\mathbf{X}$ & sd & $\mathbf{X}$ & sd & $\mathbf{X}$ & sd \\
\hline 5 & 23 & 46,78 & 19,62 & 21,87 & 11,08 & 23,30 & 8,91 \\
\hline 6 & 66 & 47,71 & 17,92 & 24,11 & 10,28 & 27,03 & 10,06 \\
\hline 7 & 252 & 55,27 & 14,39 & 27,85 & 9,43 & 31,68 & 7,88 \\
\hline 8. & 160 & 51,23 & 15,09 & 24,80 & 8,86 & 29,56 & 8,29 \\
\hline
\end{tabular}

When the mean scores of the students towards basic STEM skill levels are examined in Table 10 , it is seen that the highest average for all factors belongs to the 7th graders and the lowest average belongs to 5th graders. It is understood that in terms of all three factors, as the grade level increases, the basic STEM skill levels increase accordingly, but in the 8th grade, the skill points decrease slightly. Variance analysis was performed on the data to determine the significance level and source of the differentiation in the basic STEM skills of the students according to the grade levels and Tukey post hoc test was run to understand which groups have difference. The results of the analysis are summarized in Table 11. 
Table 11. Variance Analysis and Tukey Test Results of Basic STEM Skill Levels of Students According to Grade Levels

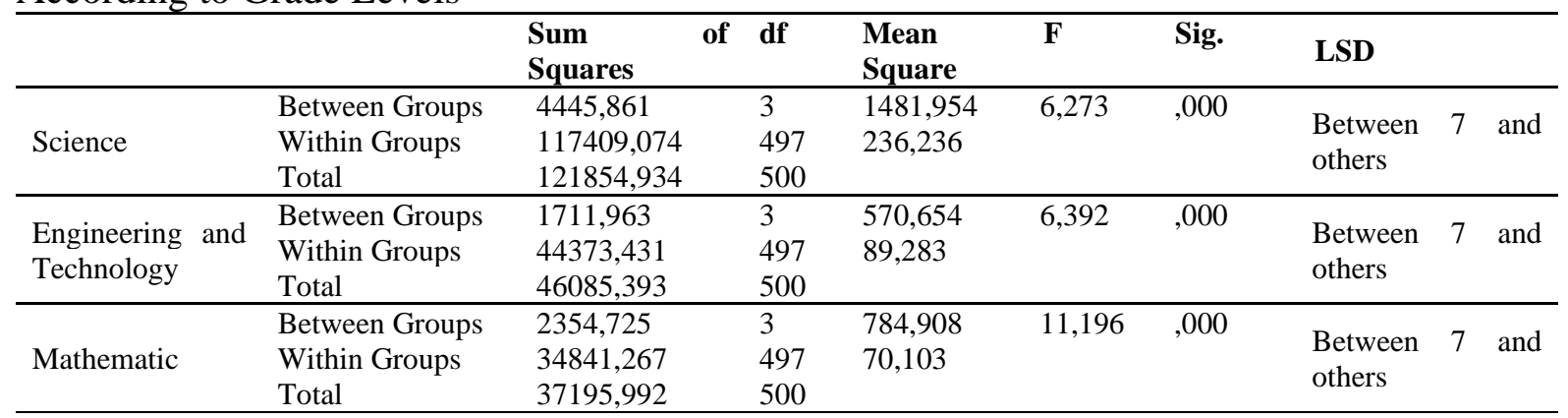

In Table 11, according to the grade levels, the students' skill levels differ significantly in terms of all factors (science factor $[\mathrm{F}(3-497)=6.273, \mathrm{p}<0.05)$; engineering and technology factor $[F(3-497)=6.392, p<0.05)$, Math factor $[F(3-497)=11.196, p<0.05])$. Tukey Test showed that the significant difference was between the 7th grade students and the students studying in other classes in terms of all three factors. When the mean scores were examined, it was determined that differentiation was the favour of the 7 th grade students. On the other hand, as the grade level increases, the mean scores have also increased, but there has been some decrease in the 8th grade. According to this, it can be accentuated that the basic Stem skill levels of the students increased as the level of the class increased, and the highest mean scores of the students belonged to the 7 th grade, while the mean scores decreased in the 8th grade.

\section{Discussion \& Conclusion}

'Basic STEM Skill Levels Scale' was adapted to determine the basic STEM skill levels of secondary school students for this study. The scale is a 7-point Likert-type consisting of 23 items that can be classified into three factors. EFA was performed for factor structure, and it was found out that the scale had construct validity. Factor correlations were calculated on the data to be able to decide the extent to which each of the items in the scale was able to measure the characteristics by the factor they belong to.

Correlation between item and the score of the factor to which the substance belongs is utilized as a criterion the level of the item scale (Balc1, 2009). In this respect, it was determined that the correlation values of the items were quite high. In addition, the values gained from each item are listed from high to low in order to determine the item discriminatory powers and then groups of 135 students were determined which form the lower $27 \%$ and upper 27\% groups. Independent sample t-test values were calculated over the total scores. It was determined that there was a difference between the lower and upper groups; in other words, it was determined that the level of discrimination of both items and factors was high.

Internal consistency coefficients; the reliability (Cronbach Alpha) formula was tested to state the internal consistency of the scale and it turned out to be quite high according to the data obtained. On the other hand, test-retest analysis was run to determine whether the scale could make stable measurements and it was defined that the scale made consistent measurements. As a result, it can be said that' Basic STEM Skill Levels Scale' is a valid and reliable that can be used for basic STEM skill levels of secondary school students.

On the other hand, the following remarks are made regarding the basic STEM skill levels of the students: Within their self-perceptions, students' basic STEM skills in science and mathematics are at intermediate level. However, it is seen that the basic STEM skills related to 
the field of engineering and technology are a bit low. When the literature studies are analyzed, there are similar results, and the science and mathematics fields seem to attract more attention. Bybee (2010) relates this to the difficulties encountered in STEM applications integrating technology and engineering disciplines into the curriculum. Bybee (2010) implies that STEM education approach is practiced in science and mathematics, and rarely emphasizes technology and engineering, and pinpoints that it is important to associate science with technology and engineering in curriculums. However, English (2016) argues that mathematics and engineering are not adequately included in STEM studies. More experimental studies can be carried out on this subject and students can make real life related applications on STEM concepts. For example, Cakir and Ozan (2018) found that in their quasi-experimental study of secondary school students that experimental group students' academic achievement in Math and their reflective thinking skills related to problem solving increased statistically compared to the control group students after STEM activities were performed.

Another finding of the study is that there is a similarity between students' genders in science and engineering - technology factors. On the other hand, basic mathematical skills of females are significantly higher than those of males. When literature studies are examined, it is noted that there are STEM studies mostly on gender differences related to attitudes (Badur, 2018; Christensen \& Knezek, 2017; Karakaya \& Avgın, 2016; Unfried, Faber \& Wiebe, 2014). For instance, Unfried, Faber and Wiebe (2014) conducted a study to measure the attitudes of 7032 secondary and 1324 high school students towards STEM subjects and their interest in STEM careers. The findings show that female and male students have similar attitudes towards mathematics, but men show more interest in most of the science fields and engineering and technology than girls. According to the authors, girls are more interested in careers such as biology and medicine than their male peers. The findings also show that the attitudes of older students towards STEM are lower. These results suggest that there is a need for new strategies to increase women's interest in engineering and technology, and the need to find ways of maintaining student interest in STEM as they age. However, Karakaya and Avgin (2016) concluded that attitudes of the female students towards STEM are higher than those of males. In a similar vein, in their study with 813 secondary school students, Christensen, and Knezek (2017) concluded that male students want to maintain a career in STEM and also show more interest in STEM fields. It was also concluded that female students had a more positive response than male ones to project activities which were presented to them in the study.

Badur (2018) conducted a thesis with 834 secondary school students in grades 5, 6, 7 and 8 to examine the interest of secondary school students towards STEM professions. It was seen that the scores of female students for the sub-dimension of science were higher than the scores of male students. This situation can be interpreted in this way: the gender variable is important in the interest of secondary school students toward professions. Another result of Badur's study (2018) showed that students who are at lower grades (5th, 6th, 7th) have more interest in STEM related professions that is significantly different from the ones at higher grades (8th). This finding does not coincide with one of the findings in this study. In this study, it was found that the basic STEM skill levels of the students increased as the class level increased, and the students with the highest average level were 7 th grade students. It was seen that in the 8th grade, the averages decreased slightly. According to this, it can be said that the education of the students in the schools contributed to their basic STEM skills, but there was a decrease in the 8th grade. That 8th grade students are going through a different preparation period or experiencing anxiety to prepare for the transition exam to high school may have been the reason to this decrease. Similarly, Potvin and Hasni (2014) found that students perceived science and technology very well until the end of their school years, but this situation declined significantly 
when they reached the last grade. On the other hand, Karakaya and Avgin (2016) examined the secondary school students' attitudes towards STEM and stated that attitudes decreased as the grade level increased in terms of mathematics.

As a result, when secondary school students grasp intersections of STEM and real-world applications, more meaningful learning will occur (Kelley and Knowles, 2016). Education researchers need to conduct more practical studies and endeavor to guide teachers to ensure that students make a connection between STEM disciplines.

\section{References}

Akgündüz, D., Aydeniz, M., Çakmakçı, G., Çavaş, B., Çorlu, M., Öner, T., \& Özdemir, S. (2015). STEM eğitimi Türkiye raporu: "Günümüz modası mı yoksa gereksinim mi?" [A report on STEM Education in Turkey: A provisional agenda or a necessity? White Paper] İstanbul: İstanbul Aydın University STEM Centre.

Ananiadou, K. \& Claro M. (2009). 21st Century Skills and Competences for New Millennium Learners in OECD Countries, OECD Education Working Papers, No. 41, OECD Publishing, Paris. http://dx.doi.org/10.1787/218525261154

Balc1, A. (2009). Sosyal bilimlerde araştırma: Yöntem, teknik ve ilkeler [Research in social science: Methods, techniques and principles]. Ankara: PegemA Pub.

Becker, K. H., \& Park, K. (2011). Effects of integrative approaches among science, technology, engineering, and mathematics (STEM) subjects on students' learning: A preliminary meta-analysis. Journal of STEM Education: Innovations and Research. 12 (5), 23-37.

Blackley, S., \& Howell, J. (2015). A STEM narrative: 15 years in the making. Australian Journal of Teacher Education, 40(7), 102-112.

Butz, W. P., Kelly, T. K., Adamson, D. M., Bloom, G. A., Fossum, D., \& Gross, M. E. (2004). Will the scientific and technology workforce meet the requirements of the federal government? Pittsburgh, PA: RAND

Büyüköztürk, Ş. (2002). Sosyal bilimler için veri analizi el kitabı [Data analysis handbook for social sciences]. Ankara: PegemA Press.

Bybee, R. W. (2010). Advancing STEM education: A 2020 vision. Technology and Engineering Teacher, 70(1), 30-35.

Carmines, E.G. \& Zeller, R.A. (1982). Reliability and validity assessment. 5th ed. Beverly Hills: Sage Publications Inc.

Christensen, R. \& Knezek, G. (2017). Relationship of middle school student STEM interest to career intent. Journal of Education in Science, Environment and Health (JESEH), 3(1), $1-13$.

Cotabish, A., Dailey, D., Robinson, A. \& Hughes, G. (2013). The Effects of a STEM Intervention on Elementary Students' Science Knowledge and Skills. School Science and Mathematics. 113(5), 215-226.

Çakır, R. \& Ozan, CE (2018). The effect of stem applications on 7th grade students' academic achievement, reflective thinking skills and motivations. Gazi University Journal of Gazi Educational Faculty GUJGEF 38(3), 1077-1100

English, L.D. (2016). STEM education K-12: Perspectives on integration. International Journal of STEM Education, 3(1), 1-8. doi: 10.1186/s40594-016-0036-1.

Eroğlu, A. (2008). Faktör analizi [Factor analyses]. In: Kalayc1, Ş. (ed), SPSS Uygulamalı Çok Değişkenli Istatistik Teknikleri [Statistics Techniques with Multi Variable in SPSS Applications], Ankara: Asil Publishers, 321-331. 
Fan, S. C., \& Yu, K. C. (2017). How an integrative STEM curriculum can benefit students in engineering design practices. International Journal of Technology and Design Education. 27, 107-129. https://doi.org/10.1007/s10798-015-9328-x

Field, A. (2000). Discovering Statistics using SPSS for Windows. London: Thousand OaksNew Delhi: Sage Pub.

Geisinger, K. F. (2016) 21st Century Skills: What Are They and How Do We Assess Them?, $\begin{array}{llll}\text { Applied Measurement in } 29 \text { (4), 245-249, } & \end{array}$ DOI:10.1080/08957347.2016.1209207

Gorsuch, R. L. (1983). Factor analysis. Hillsdale: Lawrence Erlbaum Associates.

He, Y. \& Liang L. (2019). Application of Robotics in Higher Education in Industry 4.0 Era. Universal Journal of Educational Research 7(7): 1612-1622

Hernandez, P. R., Bodin R., Elliott, J. W., Ibrahim B., Rambo-Hernandez, K. E., Chen T. W. \& Miranda M. A. (2014). Connecting the STEM dots: measuring the effect of an integrated engineering design intervention. International Journal Technology Design Education. 24, 107-120.

Jang, H. (2016). Identifying 21 st Century STEM Competencies Using Workplace Data. Journal of Science Education and Technology, 25(2), 284-301. https://doi.org/10.1007/s10956015-9593-1

Kanadl1, S. (2019). A Meta-Summary of Qualitative Findings about STEM Education. International Journal of Instruction, 12(1), 959-976. https://doi.org/10.29333/iji.2019.12162a

Karakaya, F. \& Avgin, S. S. (2016). Effect of demographic features to middle school students' attitude towards FeTeMM (STEM). Journal of Human Sciences, 13(3), 4188-4198. doi:10.14687/jhs.v13i3.4104

Kelley, T.R. \& Knowles, J.G. (2016). A conceptual framework for integrated STEM education. International Journal of STEM Education 3(11), 1-11. https://doi.org/10.1186/s40594016-0046-Z

Kline, P. (1994). An easy guide to factor analysis. London and New York: Routledge.

Korkmaz, Ö., Çakır, R. \& Uğur Erdoğmuş. (2020). A validity and reliability study of the Basic STEM Skill Levels Perception Scale and Student's Basic STEM Skill Levels. International Journal of Psychology and Educational Studies, 2020, 7(2), 111-121

Lotta C. Larson \& Miller T. N. (2011). 21st Century Skills: Prepare students for the future, Kappa Delta Pi Record, 47:3, 121-123, DOI: 10.1080/00228958.2011.10516575

NGSS. (2018). DCI Arrangements of the Next Generation Science Standards. Available at: https://www.nextgenscience.org/sites/default/files/NGSS\%20DCI\%20Combined\%2011.6.13.pdf.

Ostler, E. (2012). 21st Century STEM Education: A Tactical Model for Long-Range Success. International Journal of Applied Science and Technology 2(1), 28-33

Potvin, P. \& Hasni, A. (2014). Analysis of the decline in interest towards school science and technology from grades 5 through 11. Journal of Science Education and Technology (JSTOR), 23(6), 784-802. doi: 10.1007/s10956-014-9512-x

Sanders, M. (2009). STEM, STEM education, STEMmania. The Technology Teacher, 68(4). 20-26.

Scherer, R.F., Wiebe F.A., Luther, D. C. \& Adams J. S. (1988). Dimensionality of coping: Factor stability using the ways of coping questionnaire, Psychological Reports 62(3), 763-770. PubMed PMID: 3406294

Sneideman, J. M. (2013). Feature Story. Natural Start Alliance. Available at: https://naturalstart.org/feature-stories/engaging-children-stem-education-early

SNAP (2018). SNAP Assessment for NGSS. Available at: https://snapgse.stanford.edu/snapassessments-ngss 
Tatlıdil, H. (2002). Uygulamalı çok değişkenli istatistiksel analiz [Applied multivariate statistical analysis], Akademi Pub, Ankara

Tutak, F. A., S. A., \& Tezsezen, S. (2017). Collaboratively Learning to Teach STEM: Change in Participating Pre-service Teachers' Awareness of STEM. H. U. Journal of Education, 32(4) 794-816.

Unfried, A., Faber, M. \& Wiebe, E. (2014). Gender and student attitudes toward science, technology, engineering, and mathematics. American Education Research Association (AERA) 2014 Annual Meeting, Philadelphia, PA. https://eval.fi.ncsu.edu/wpcontent/uploads/2016/03/AERA-2014-Unfried-Faber-Wiebe.pdf

White D.W. (2014). What Is STEM Education and Why Is It Important? Florida Association of Teacher Educators Journal 1 (14) 1-9.

Yildırım, B. (2016). An analyses and meta-synthesis of research on stem education. Journal of Education and Practice. 7(34), 23-33.

Yılmaz, A., Gülgün, C. \& Çağlar, A. (2017). Teaching with STEM applications for 7th class students unit of "force and energy": let's make a parachute, water jet, catapult, intelligent curtain and hydraulic work machine (bucket machine) activities. Journal of Current Researches on Educational Studies (JoCuRES), 7(1), 97-116. 